\title{
I am because you are ${ }^{1}$
}

Emilyn Claid, Roehampton University

\begin{abstract}
This article expands a keynote address given at the conference Ethics \& Repair, Dance \& Somatics Practices, at Coventry University (2015). Part One is an effort to understand a basic ethical tenet - respect of otherness - inviting an understanding of how to be with difference through a somatic sense of self as related, separate and in between. Part Two draws on this respect of otherness to offer a second discussion concerning dance training for performance. Somatic practices nurture an ethical relationship to others and the environment, contributing to physical and psychological change. Over the past twenty years somatic practices have come to form the foundation of contemporary dance training, disrupting competitively attained acquisition and achievement of spectacular technical skill. I Am Because You Are gives this dilemma in dance training some air space, to blow through currents of thought.
\end{abstract}

\section{Keywords}

ethics

otherness

relatedness

training 
technique

somatics

\section{Introduction}

This article expands a keynote address given at the conference Ethics \& Repair, Dance \& Somatics Practices, at Coventry University (2015). I am interested in two linked discussions. Part One is an effort to understand how we might physically practice a basic ethical tenet - respect of otherness. I am exploring this philosophically and bodily, inviting an understanding of how to be with difference through a sense of separateness and relatedness. I am proposing a self supported separateness, experienced by giving somatic attention to one's body in the environment, allowing us to relate to one another as the different beings that we are and giving space for something else happening in between us. With the basis of a three way dynamic of relationship: separateness, relatedness and in-between-ness I move into Part Two to offer a second discussion concerning dance training for performance. Somatic practices are, for the most part, considered to be ethical, for bodies and between bodies, nurturing a mindful relationship to the environment and contributing to physical and psychological change. Over the past twenty years these practices have come to form the foundation of contemporary dance training. I am suggesting that somatic movement practices combined with technical skill-based dance training has instigated a dilemma, as ethical somatic practices can interrupt the competitively attained acquisition and achievement of technical skill. Given the title of the conference, Ethics and Repair: Continuing Dialogues within Somatic Informed Practice and Philosophy, I am opening up this can of worms again (Claid 2006, 
$2012,2016)$, and giving the dilemma some air space to blow through currents of thought.

\section{Part One}

\section{Ethics of Otherness}

Living ethically requires a respect for difference between one and another. I am seeking to understand this tenet from a perspective of bodily practice. How do we be with an ethical respect for difference in our bodies? How might somatic bodywork support us to transfer and translate ethical concerns for diversity into our every day existence? I begin this enquiry with an amateur's curiosity for a philosophical frame, referencing philosophers Emmanuel Levinas and Alain Badiou.

'The Other faces me and puts me in question' (Levinas 1999/1969: 207). Introduced to Levinas during my training as a Gestalt psychotherapist, I am particularly impacted by his existential, phenomenological, personally informed thinking on intersubjectivity. His ethics of otherness, a respect for difference that he devoted his life to testing, is a disarming of an identifiable sense of ' $\mathrm{I}$ ' in the face of an other, whereby my responsibility to another pre-exists my right to be.

For Levinas, ethics is the new name of thought, thought which has thrown off its 'logical' chains (the principle of identity) in favour of its prophetic submission to the Law of founding alterity. (Badiou 2002: 20 original emphasis) $)^{2}$ 
In his passionate essay on Ethics (2002) Badiou places Levinas' ethics alongside principles on which the Meta term Ethics is founded in the West. Simply, Man as a consequence of His ability to reflect on life and death, good and evil constructs, for himself, beliefs of Immortality and Universal Subjectivity and from his subjective position defines Good and Evil, where Good becomes Sameness and Evil is Otherness. ${ }^{3}$

And this is why the reign of 'ethics' coincides, after decades of courageous critiques of colonialism and imperialism, with today's sordid self-satisfaction in the 'West', with the insistent argument according to which the misery of the Third World is the result of its own incompetence, its own inanity - in short, of its subhumanity. (Badiou 2002: 13)

Following on, it is a small step for Badiou to advance that every effort to unite people around a positive idea of the Good... becomes in fact the real source of evil itself... Every will to inscribe an idea of justice or equality turns bad. Every collective will to the Good creates Evil. (2002: 13) 
I understand this to mean that whichever civilized community we consider, west or east, each has an idea of Goodness that all must obey and if you are outside that collective sameness you are evil. So, otherness becomes dangerous.

Against this western backdrop Levinas' testing to unfix the monolithic concept of Identity is an attempt to undo ethics from its trapping boundaries of Universal Subjectivity, Good and Evil. The problem is, Badiou emphasizes, because of the demands of western logic, Levinas' ideas can become a jumbling confusion between philosophy and theology, a 'decomposed religion... a dog's dinner... We are left with a pious discourse without piety, a spiritual supplement for incompetent governments, and a cultural sociology preached' (Badiou 2002: 23). ${ }^{4}$ In other words, Levinas' ethics of otherness as a testing of new thinking about being with difference is submerged under the clutches of civilized western logic.

While Ethics is contemplated at the level of logic and discourse Levinas' concept of an ethical respect of otherness will remain a 'decomposed religion'. We need to find ways to sense ethics bodily, bring Levinas' thinking into embodied sensation, encountering how mind-body experience supports a way to be with the unknown-ness of one another. Moving towards this potential, Badiou continues saying 'there is no ethics in general. There are only - eventually ethics of processes by which we treat the possibilities of a situation' (2002:16). This intimates that we might move away from grand logical Fixings and move into more fluid relations between things. I am implying that we do this through being with our bodies - questioning habitual movement as somatic practitioners, for this is where creative change potentially happens, right here in the meeting 
between us. Not only might a body-based practice support each of us to live an ethical life, but also something else might happen in between that is unknown in the exchange - something creatively uncertain and logically impossible. ${ }^{5}$

\section{Developmental movements}

I am falling from the lofty abstractions of Ethics to micro embodied concerns, moving between philosophy and sensation. Falling towards an embodied ethical process begins with a glance at early developmental movement patterns between carer and infant, a micro relationship, which Ruella Frank, Gestalt psychotherapist and founder of Center for Somatic Studies in New York suggests affects all consequent relationships $(2001,2011)$. For here, in this primary contact, germinates a sense of self in the world.

When we are born, we are dependent on others for survival and an emerging sense of a separate self develops through relationship with a primary carer. Writing this last sentence and thinking about how we embody a respect of difference raises a paradoxical question: An ethical life requires a respect for difference between self and other, yet how might we experience this way of living when, in our early lives, we are dependent on each other for survival and our individual sense of self develops through attachment to another?6 Before a baby acquires spoken language, in the first year of life, her needs are met through movement, experienced in relationship with carer and environment. Body and brain develop in relation to others and to environment. During this time an infant develops movement patterns and movement memory, physical and psychological, that remain with him or her throughout life. 
Using a sequence of yielding, pushing, reaching, grasping, pulling and releasing movement, a baby communicates what he wants and needs from his parents and expresses how he reacts to what his parents want and need from him...They are essential to character development in that they become the preferred and routine ways we dynamically adjust, making them simultaneously psychological and physical. (Frank and LeBarre 2011: 21)

Somatic practitioners will be aware of these relational movements. I would like to draw attention to the first two: yield and push. This combination is integral to an infant's relationship with environment and carer. Through an inseparable Mobius-like bond of yield and a push with the environment we become self supported and, through a bond of yield and push with a primary carer, we make contact and become present to each other.

Whereas how one yields with allows one to join another, how one pushes against allows one to differentiate from another. Experienced as an almost simultaneous shuttling back and forth between one and another, yield/push and push/yield are essential to and necessary for interpersonal meeting throughout the lifespan. (Frank and LeBarre 2011: 27)

Turn to face the person sitting next to you. Focus for a moment on your breathing, sensing your feet on the floor and your body in relation with the chair. Aware of this support from the environment, slowly place the palms of your hands against 
the palms of your partner's hands. Gently experiment with yielding and pushing towards and away from contact with your partner's hands. Work slowly, responding to each other's yield and push. Gradually let go of contact and talk together about your experiences. When did yield become push? When and how was your sense of safety affected by contact towards and away? When did you feel vitally present? When did you not? (Conference presentation task one) ${ }^{7}$

\section{Uncertainty of consistency}

An infant has more chance to develop a sense of self in relation, when there is a consistency of presence - baby yields to carer who holds her so baby can push away. Yet even with the best parenting in the world, there is no certainty of this vital contact. There is no certainty that you will be there when I yield, or vice versa. Not only do the events of every day life get in the way, but carer and infant bring to the meeting their own embodied histories. The other we are dependent on is sometimes there and sometimes not. Sometimes he or she is there too much and sometimes far too little. Each mother or carer has her own embodied movement history, passed on from her ancestors, life experience and needs for attachment._These are brought to the meeting with the infant who has his or her different needs and embodied dynamics. Ways of moving develop through this primary relationship affecting our physical and relational patterning throughout life. 
Fundamental movements always arise in relation to the surrounding environment and, particularly in the first year, in relation to the parents... Parents actions become entwined with their baby's actions ... Parents express their own intention, attitudes, perceptions and feelings through their own movement... and all of these... are directly relayed to their baby through this moving dialogue. (Frank and LeBarre 2011: 23)

The unpredictable nature of developmental movement relations implies that ambiguity and unknown-ness are inherent and integral to being alive. We are safe and unsafe at the same time; we need each other to be our separate selves yet our selves develop in relation. I am because you are and this is an uncertain existence at the best of times.

We are dependent on each other for survival and that dependence is fraught with inconsistency. In western culture, living with uncertainty of relationship can feel intolerable. Hence the construction of Universal Subjectivity that Badiou asserts (2002). In western culture, feeling unsafe can come with fear of abandonment and death. What is at stake with feelings of uncertainty in relationship is that if you are not there, I might not be here either. No contact. Which brings us right up close to what existential psychotherapist Ernesto Spinelli would call a death anxiety.

Temporal life anxiety seeks to point us to our experience of the fundamental uncertainty of being, such that every step we take, every act we initiate, expresses, at its heart, our inevitable movement towards non- 
being through unknown and unpredictable life circumstances. (Spinelli 1997:1, cited in Van Deurzan 2005: 73)

\section{Fixing the other}

Rather than embrace unknown-ness and uncertainty of relationship, anxiety leads us to fix each other. We interpret otherness, making ourselves safe by fixing the other in our own field of understanding. If I am feeling unsafe I might try to own, appropriate or possess you, or try to make you like me, attempt to shape you in my own likeness, or become like you. To rely on you being there for me I might hold onto you. If I cannot do this I might reject you. We identify with each other and interpret each other for ourselves. We even keep each other alive when death would be so much preferable, because to face another's death is to face our own.

Face your partner again. Look at each other. Just look.

Take it turns to slowly lower your gaze towards the ground. Remain with your eyes cast down for a while and then return to look again at your partner. Notice how you are affected, both doing and witnessing this action with your partner. Discuss. (Conference presentation task two) 8

This experiment allows us to recognize how we tend to interpret meaning as something that is sourced in the other. When the person I am meeting lowers her gaze, I interpret her as unhappy. But it is my unhappiness I feel, not hers. We 
tend to lose touch with owning our felt sensations that we bring to the encounter from our own backgrounds. Instead we transfer, project and interpret the other according to our pre-constructed understanding of the world.

Within this operational field a respect of difference can become a fixed affair, identifying otherness as sameness. As Luce Irigaray describes from her feminist philosophical perspective:

In the attempts at individuation made since the dawn of ancient Greek culture, the subject has defined itself by imposing forms that framed pre-given matter and dominated it... Fixed by identificatory parameters, the other, with a benevolence that is all the more warm because it remains abstract, is summoned to come and join those who already make up the ranks of supposedly confirming human beings. So not other: same. (2004: 67)

Fixing the other as the same is what Levinas seeks to overturn when he writes of intersubjectivity which is 'not reversible, equal or symmetric... face-to-face is an intersubjective encounter where my response-ability for you preexists my right to be' (Levinas 1982: 103). If I come face to face with you, my life and yours become intertwined and harming you would be to harm myself.

Fear for the other... is my fear, but is in no way an individual's taking fright...Emotion therefore consists in being moved - being scared by 
something, overjoyed by something, saddened by something, but also in feeling joy or sadness for oneself... There is a double intentionality in the by and the for and so there is a turning back on oneself and a return to anguish for oneself, for one's finitude: in the fear inspired by the wolf, an anguish for my death. (Levinas 1984 in Sean Hand 1989: 84 original emphasis) ${ }^{9}$

Because intersubjectivity implies uncertain inconsistency that is inherent to relationship, so we incline towards fixing and interpreting others to provide safety and certainty. When we fix and interpret difference as sameness to create safety we nurture Subject/Object binaries and the fear of otherness persists. I am putting forward a premise that fixing as Same occurs when too much emphasis is given to the expectations of the other to be there for us and not enough emphasis given to self support, yield/push between body and environment. The practice of which is core to the development of a sense of separate self in relation to others. We tend to focus too much on expectations of others and not enough on selfsupport - a relationship between body and environment, the ground.

\section{Accepting interpretation}

What if the first step to undoing fear of uncertainty of encounter with otherness is to fully accept that we fix and interpret?

Gestalt psychologist Staemmler writes that because each of us is grounded in our 'cultural coinage, our personal history, our material conditions' (2009: 20) we 
cannot separate our perception from our understanding of the world. We do not perceive something without also understanding it as something. 'Our understanding of any situation necessarily begins with a prejudice or, to put it a little milder, with a pre-understanding' (Staemmler 2009: 85).

Staemmler's emphasis on awareness of prejudice emerges against a backdrop of an Husserlian phenomenological objective that to be true to the other, we need to bracket our interpretations, and eliminate our own modes of thinking entirely, denying our pre given prejudices. Different to Levinas' existential intersubjective approach to otherness, Husserl's stated objective was to 'eliminate traditional modes of thinking completely, to recognize and tear down the bounds of the mind' and to establish 'an entirely new attitude which is opposed to the natural ways of experience and thinking' (Husserl 1922: 3) through his method of 'epoche' and 'phenomenological reduction' (Staemmler 2009: 71).

Husserl's bracketing or 'phenomenological reduction' (Husserl 1922: 56) becomes one of transcendence, the creation of a 'transcendental ego', a notion that one can 'clean your mind of all pre-understandings' (Staemmler 2009: 71). That somehow by transcending my own body and history, deflecting from my own affecting behaviour and thoughts, a God-like bracketing of myself in the face of an other, I will truly see the other as not myself. Staemmler is claiming that this is not only impossible but we risk extracting our human-ness from the encounter altogether. 
With an emphasis on embodied ethics in this writing, transcendence is not a way to approach an ethical respect for difference, as the aim is being aware of our bodies and cultural backgrounds, when we meet each other. The point is, to recognize that we interpret, and that this interpretation is co-created, by you and me, based on our embodied histories and experience. To accentuate earlier writing - if I see you yawn and fall asleep while I am talking, I might interpret you as bored or tired, while actually you might be just taking oxygen into your body. The consequence of my interpretation will be to speed up or do a little dance to keep you entertained. Catching The Simpsons (2016) cartoon: I watch Bart Simpson walking down a street towards a bank (money). He is eating a toffee apple. There is a sign on the door of the bank saying 'no food allowed', so he puts his hand, with toffee apple, into his pocket. He enters the bank and everybody thinks he has a gun in his pocket so they cower on the floor, and he is taken down by a stun gun! We get the joke and laugh at our own mistaken interpretation!10

What we are interpreting in thought and feeling is co-created, yet how I am affected is my response-ability, we each come to each encounter with our own experiential history. At each here and now encounter we jointly create whatever happens, from our separate and different experience and our togetherness, in the present moment. ${ }^{11}$ When we notice the fixed interpretations that we each bring to any meeting with difference, we might begin to shift the paradox of dependency and approach a place of curious dialogue. 
I focus on breathing and allow my face a sensation of falling - out of dependence on you, sensing my relationship to the ground that supports me as I am falling. I am letting go of fixing on my relationship with you to support me; I am letting the ground support me as I fall. ${ }^{12}$

With this action I am demonstrating how I connect with the environment, as a key element of self-support. Falling towards and pushing against, I come into contact with the ground and I become self-supported. When I am self-supported I can separate from you. When I am separate from you I can see you as not me. This 'I' of relatedness depends on my ability for separateness. Separateness is possible if we support ourselves somatically with the environment. From here I might see you as different to me. I no longer need to fix you as the same; I no longer need you to fix me.

Make yourself comfortable in your chair and come into your breathing. Sense your feet on the ground, how you can yield and push your feet into the ground and the ground supports you. Sense your back, pelvis and legs against the chair and as you yield into the chair how it supports you to push away. Notice in yielding and pushing that you create a sensorial contact boundary between your body and the environment.

Spend time here, maintaining this self-supporting practice and see if you can look towards your partner as you be with your practice. What do you see? Who do you see? Is what you see different now you are 
focusing on your bodily sensations in relation to your environment? What do you sense in yourself? What kind of space opens up for you in between you and your partner? This is your experience. Discuss with your partner. (Conference presentation task three)

Embodied somatic support between body and environment (developing a contactful yield and push with the environment) encourages a self-supported vital presence with which to notice and respect differences between us. Gestalt psychotherapist Richard Hycner's writing on intersubjectivity emphasizes separateness in relatedness.

There are the two primary attitudes that a human being can take toward others. One is an attitude of natural 'connection' the other, natural 'separation' (Buber 1958). Both are essential. This often is misunderstood... We are always seeking a balancing point between our separateness and connectedness to others. In fact, it is the creative tension... that is the hallmark of healthy living. (Hycner 1995: 8, emphasis added)

Separateness emerges through relationship and is as necessary as relatedness ${ }_{2}$ to open up curiosity and respect in a space between us for something else to happen.

'En-dash'13 
Dialogic relations take place between you and me. This ambiguous, between space of encounter is where creative exchange takes place. ${ }^{14}$ The en-dash is a powerful symbol for theologian Martin Buber and his notion of intersubjectivity as a dual act of distancing and relating, separateness and togetherness when he uses the terms I-Thou and I-It. 15

In his poetic writing on contact improvisation Williams (1996) references George's article on ambiguity and the third state of potentiality (1988).

All binaries are really hidden - and dynamic - triads... the crucial factor here is not how many ways two different units can relate to each other, but recognition that this 'third element' is not a unit but an axis, not an entity but a state of being, less a relationship than an act of relating'. (George 1988: 78-80 cited in Williams 1996: 25)

I am because you are, is not about closing but opening a gap between us, a gap of dialogic creativity. As Williams delineates (1996), many writers name this third space. It has been called between-ness, becoming space, interval, creative void, filled emptiness, non-place, liminality, potentiality and dialogic contact boundary. Whatever it is called, and trying to name it may be a way to fix it - an encounter with unknown-ness between us, as an encounter with otherness, is a potential space for living change. 
I will never know you, you will never be mine, and this not is what constitutes you as a possible you for me, as a reality or a being irreducible to my I. Certainly, we may sometimes merge in some fusional permeability, ... in some immersion in a dominant culture. But the return to our difference will give us back to duality, to dialogue. (Irigaray 2004: 75)

What happens at our encounter moves in that gap between I - You. That en dash between one thing and another, which divides and joins, where something else is suggested that is not either one, yet requires both is full of what is between. Part one of this article has emphasized self-supported separateness to encourage relatedness and in between-ness as a basis for an ethical respect of otherness. I have been giving attention to sensorial contact between body and environment as a potential practice, to explore respect for diversity and difference as a bodily experience. Respecting otherness is between you and I and requires somatic attention to my body in environment, offering a separateness that allows me to see you as different to me and opens a space between us to explore.

\section{Part Two}

In this discussion I am thinking about how ethics as a respect of difference - a three-way play of separateness, relatedness and in between-ness - might affect dance training for performance. I would like to shake out some existing tensions between somatic learning and technical training for performance. I am hinting that the three way ethical process mentioned above can sometimes get lost in our well meaning care for teaching others. Teaching somatic-based dance 
training often focuses more on relatedness, seeking confluence on bodies and between bodies, rather than tensions of difference. The contemporary dance community cares for its members, dancers improvise together, make performance together, share movement languages and collaborate together. Yet I wonder how much we engage with difference. Often we work in codes that are presumed between us, where respect of otherness is sometimes overlooked. Provocatively, I wonder if our care for each other tends to be based on making each other similar, over-riding the un-known of difference.

\section{Somatic experiments}

One initiating context for this dilemma can be traced back to the 1970s and the introduction of somatic movement practices into UK professional dance training. I have written elsewhere of the tumultuous affects of somatic practices onto technical dance systems such as ballet and modern dance techniques (2006).

Back then, somatic movement practices shook traditional dance aesthetics and training to the core, for many of us who were silenced and/or injured psychologically and physically and unable to move outside traditional fixed codes. Somatic bodywork saved and served us well: Mary Fulkerson's releasebased imagery, Steve Paxton's small dance, Alexander 's dropping and lengthening around a central axis, and Bonnie Bainbridge Cohen's deep listening and sensing in Body Mind Centring. Somatic practice seeped through habitual thought and movement patterns through breath, sensation, anatomy, imagery and improvisational curiosity. 
With the introduction of somatic approaches to movement in the 1970s, dance practice was no longer a hierarchy between those that could and those that could not. Dance was less about particular able-bodied people, or about physical image, there was no fixed image to produce, no mirror-based learning, no external judge. This encouraged a socially engaged ethical dance practice - although enthusing mainly white communities. ${ }^{16}$

To begin, somatic work was internally focused and the work was about personal discovery as alluded to by Body Mind Centring practitioner Linda Hartley.

When we practice on our own, it is mind touching body, and a similar sense of clarity can be experienced when our mind meets with the energy and movement of our own body. In this way the body is seen to be truly an instrument of expression of the mind. (Hartley 1983: 13)

This inwardly focused work was/is necessary for unravelling habitual externally focused movement patterns and begins a process of repair for dancers. In the 1970s our need to look inwards towards bodily sensation was a rejection of, but emerging out of, a modernist enlightenment notion of spectacular stardom. Just as feminism, also emerging out of an era of Enlightenment, tended towards a search for essentialism, so somatic practitioners, tended towards a belief that looking inwards we might find an essential truth, or origin for being, a root to health and well-being. We needed to look after ourselves. But we were not looking inwards to support singularity. We knew, through somatic work, that in 
order to begin to relate to each other and the world of objects and things, we must first (and continuously) sense ourselves in our bodies and in relation to the environment, the ground. So although our early experiments were inwardly focused, somatic work was/is never about finding a single truth on one's own. Somatic practice is always in relation to our environment - sensing encounters between body and breathing, body and ground, body and body and between body and site. ${ }^{17}$

\section{Teaching, training, learning}

Following the 1970s experiments, somatic movement practices were integrated into dance training across university, conservatoire, professional dance and therapeutic contexts, becoming core to movement understanding, nurturing mind-body intelligence.

Somatic learning happens in spaces in between teachers and students as New Dance editor Jane McDermott writes in an interview with Steve Paxton in 1977: 'Contact is the only technique I've come across where the work is really the teacher' (1977: 5). About 32 years later, Erin Manning, Canadian cultural theorist, philosopher and practicing artist echoes McDermott's words.

Relational movement means moving the relation. Moving the person will never result in grace, intensity of movement can only be felt when the in-between - the interval - created by the movement-with takes hold. (Manning 2009: 108-09) 
Ethically sound, yet a dilemma emerges for those wishing to engage with and earn a living in, dance theatre performance as spectacle. This dilemma bubbled to the surface in 2014 when three leading choreographers, Lloyd Newson, Hofesh Schechner and Akram Khan raised concern over UK's contemporary dance training. Lloyd Newson, Artistic Director of DV8 says of UK conservatoires,

As leading contemporary dance companies, we would hope to employ graduates from these institutions, which are all in receipt of public subsidy as well as student tuition fees. Unfortunately the students, more often than not, lack rigour, technique and performance skills. ${ }^{18}$

What part might somatic teaching and learning play in contributing to a lack of 'rigorous' technical and performance skills for spectacle?

To meet the demands of the production market for spectacle, with all its capitalist trimmings, conventional dance training has tended to function most successfully through hierarchies of teaching and learning where students leave their every day bodies outside of the studio on a daily basis, and consistently repeat movements that are alien to their bodies and repeat them until they are patterned and effortless. To earn a living in a world of dance spectacle, dancers must develop ever more impressive technical skills, to satisfy spectators who have paid money to sit and be 'wowed'. Dancers train to become bodies 'for hire'; they are trained 'in order to make a living at dancing' (Foster 1992: 494). 
A somatic, relational teaching practice interrupts this process, introducing bodymind awareness, sensation and presence and re-introducing effort into movement. Once this interruption is in motion, demanding a student to repeatedly blank out sensation in order to get her leg up above her head, balance endlessly on one leg or look the same as everybody else in unison, becomes a painful contradiction to somatic-based ethical face-to-face interaction.

The elephant in the room (if I may use such an idiomatic expression around dancers) is whether a practice of ethical respect for difference and diversity is at all feasible within hierarchical working processes, production and performance of spectacle. Suffice to say, for now, as long as audiences need the reassurance of spectacular dancing - an ultimate fixer of relational uncertainty - teaching technical skill and producing spectacular dance will persist.

\section{Potential in difference}

What a dilemma! How can we be ethical and spectacular? Contemporary dance teachers have found ways of moving that combine the polarities of internal and external focus, and teach from a merged experiential place. Many teachers experienced somatic practices after years of conventional trainings. I include myself when I say contemporary dance teachers hold embodied memories of technical spectacular training and somatic awareness on their bodies when they teach. This might be problematic when we are teaching students who have not experienced the externally driven push towards rigorous technical achievement, the highly competitive individualism of conventional training. As somatic and 
technical dance teaching gets jumbled up together there is tendency towards 'middle mush' (Claid 2006: 140), in relation to spectacular dancing. Perhaps there is too much yielding towards and not enough pushing against. Somatic movement approaches offer remedy and repair for dancers and teachers, yet the same practices act as a rupturing virus for spectacular performance and training.

The benefits of somatic awareness are many: furthering an ethical respect of otherness; offering physical and psychological health; undoing colonialist imperialism in our thoughts and on our bodies; furnishing actors with body awareness and grounding for body-based performers, encouraging environmental awareness for site specific performers - yes. Yet dance theatre training for choreographic spectacle requires externally driven technical skill, and is answerable to the efficient management and organization of marketable, economically driven performance production. Which is effectually an oppositional approach. Can training for spectacular dancing be ethical? ${ }^{19}$

Rather than merge these two polarities into an ethically sound release-based technique class (for instance), why not honour the polarities. Lie on the floor and do release-based imagery for two hours and do a ballet/Cunningham class - not one class that does both, called release-based contemporary! Perhaps we might let dancers in training experience the polarities and sort out how these differences land on their minds and bodies. Trust students to make sense of inbetween, creating something else by experiencing the lively creative tension of extremes of difference. 
I don't know... What pleases me is not necessarily what pleases you. If I slow down to sense my separate self/body in relation to the environment, meeting you from this self supported space, I am more likely to notice how my interpretations of you is a consequence of my experience, not yours. I am more likely to notice and be curious about how your needs are different to mine. If nothing else, I am more likely to respect the vast range of styles and genres of dance performance that currently shape the world of contemporary dance, whether a massive dance theatre spectacle or a one-to-one intimate encounter in a library corner. 


\section{References}

Adair, C. and Burt, R. (2013), 'The British dance and the African diaspora research project', http://www.dmu.ac.uk/research/research-faculties-andinstitutes/art-design-humanities/dance/british-dance-african-diaspora/british$\underline{\text { dance-and-the-african-diaspora-research-project.aspx..Accessed August 15th }}$ 2014

Badiou, A. (2002), Ethics: An essay on the understanding of evil', https://books.google.co.uk/books?id=eLfF6z2BtPgC\&pg=PA24\&lpg=PA24\&dq= ethics+and+respect+for+difference \&source=bl\&ots=wRjK5kIrhe\&sig=0f5YzNpl $\underline{\text { WbtHVaiLXlEoLVwCs0s\&hl=en\&sa=X\&ved=0ahUKEwjZvr- }}$

QwJLKAhXCXRQKHW2IDdAQ6AEIQjAG\#v=onepage\&q=ethics\%20and\%20respe ct\%20for\%20difference\&f=false. Accessed December $\underline{3 r d} 2015$.

Bainbridge Cohen, B. (2012), Sensing, Feeling Action, USA: Contact Editions.

Bowlby, J. (1969). Attachment. Attachment and loss: Vol. 1. Loss. New York: Basic Books.

Buber, M. (1958), I and Thou, New York: Scribner's Sons.

_ (1965), The Knowledge of Man: A Philosophy of the Interhuman, New York: Harper Torchbooks. 
Claid, E. (2006), Yes? No! Maybe... Seductive Ambiguity in Dance Theatre Performance, London: Routledge.

__ (2012), 'Rise \& decline. Reflections through Danscross', Theatre Dance \& Performance Training.

__ (2013), 'Can I let you fall?', Performance Research On Falling, 18:4 pp.73-82 (2016), 'Alive or dead? Face to face with contemporary dance', Choreographic Practices Questioning the Contemporary, 7:1, p. 143-158.

Deleuze, G. (2004), Difference and Recognition, New York: Continuum International Publishing Group Ltd.

Deurzan, E. Van and Arnold-Baker, C. (eds) (2005), Existential Perspectives on Human Issues, New York and Hampshire: Palgrave Macmillan.

George D. (1988), 'On ambiguity: Towards a post-modern performance theory', Theatre Research International, 14:1, pp. 78-80.

Goffman, E. ([1967] 2005), Interaction Ritual Essays in Face-to-Face Behavior, New Brunswick, NJ: Transaction Publisher.

Hand, S. (1989), The Levinas Reader, Massachusetts and Oxford: Blackwell Publishing Ltd. 
Hartley, L. (1983), 'Body Mind Centering: An introduction', New Dance, 27:

Winter, pp. 11-13.

Husserl, E. (1922), Ideen zu einer reinen Phänomenologie und phänomenologischen Philosophie, Tübingen: Niemeyer.

Hycner, R. (1995), Relational Approaches in Gestalt Therapy (eds L. Jacobs and R. Hycner), Santa Cruz: Gestalt Press.

Levinas, E. (1982), 'Philosophy, justice and love', in E. Levinas (ed.), Entre Nous, London: Athlone Press, pp. 103-21.

__ (1984), 'Ethics as first philosophy', in Justifications de l'ethique,_Bruxelles:

Editions de l'Universite de Bruxelles, pp. 41-51, translated for Hand, S. (1989), The Levinas Reader, Oxford: Blackwell Publishers Ltd.

__ (1985), Ethics and Infinity, Michigan: Duquesne University Press.

__ (1999/1969), Totality and Infinity, Michigan: Duquesne University.

Foster, S. L. (1992), 'Dancing bodies', in J. Crary and K. Sandford (eds), Incorporations, New York: MIT Press, pp. 480-95. 
Frank, R. and LeBarre, F. (2011), The First Year and the Rest of Your Life, New York: Routledge.

Irigaray, L. (2004), Key Writings, London New York Continuum.

Manning, E. (2009), 'The elasticity of the almost', in A. Lepecki and J. Joy (eds), Planes of Composition Dance theory and the Global, London, New York, Calcutta:

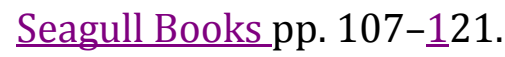

McDermott, J. (1977), 'An interview with Steve Paxton', New Dance, no. 4: Autumn pp. 5-8.

Paxton, S., 'Small Dance', http://bodycartography.org/portfolio/smalldancestevepaxton/. Accessed May $\underline{15 \text { th } 2015}$

Originally from Contact Quarterly, Volume 11, No. 1, Winter 1986; reprinted in CQ's Contact Improvisation Sourcebook, Volume 1, 1997.

Spinelli, E. (1997), Tales of Unknowing: Therapeutic Encounters from an Existential Perspective, London: Duckworth.

Staemmler, F. (2009), 'The willingness to be uncertain', in L. Jacobs and R. Hycner (eds), Relational Approaches in Gestalt Therapy, Santa Cruz Gestalt Press pp. 65-111. 
Spinelli, E. (1997) Tales of Un-Knowing: therapeutic Encounters from an

Existential Perspective London: Duckworth

Stawman, S. (2009), 'Relational Gestalt: Four waves', in L. Jacobs and R. Hycner (eds), Relational Approaches in Gestalt Therapy, Santa Cruz: Gestalt Press, pp. 1136.

Stern, D. (1998), The Interpersonal World of The Infant, Great Britain: Biddles Ltd.

The Simpsons (1989-2016) TV series created by Matt Groenig. USA: Fox

Broadcasting Company,

Tufnell, M. and Crickmay, C. (2014), Body Space Image, London: Dance Books.

Wheeler, Gordon (1997), 'Self and shame', in Gordon Wheeler and Robert Lee (eds), The Voice of Shame Silence and Connection in Psychotherapy, Gouldsboro: Gestalt Press, pp. 23-57.

Williams, David (1996), 'Working (in) the in-between', Writing on Dance,_15:

Winter (The French Issue), pp. 22-38.

http://www.criticaldance.org/2015/04/10/leading-choreographers-raiseconcerns-over-uk-contemporary-dance-training/.Accessed May $5^{\text {th }} 2015$ 
http://www.theguardian.com/stage/2015/jul/12/contemporary-dance-debate-

shechter-khan-newson-laban-students-training Accessed July 12th 2015

https://en.wikipedia.org/wiki/Dash Accessed October 10th 2015

http://roehamptondance.com/falling/ Accessed October 15th 2015

\section{Contributor details}

Emilyn is a professor at University of Roehampton. She is also a Gestalt psychotherapist with a private practice. Her career stretches back to the 1960s when she was a ballet dancer and the 1970s when she was co founder of X6 Dance Space in London and co-editor of New Dance Magazine. In the 1980s she was artistic director of Extemporary Dance Theatre and in the 1990 worked as an independent artist. In 1997 she published a book, Yes? No! Maybe... Seductive Ambiguity in Dance Theatre Performance (Routledge, 2006). Between 2003 and 2013 Emilyn was Director of BA and MA Choreography at Dartington College of Arts and Falmouth University. Research projects interweave the disciplines of choreography, writing, performing and psychotherapy, and she presents her research internationally.

Contact: 
University of Roehampton, Froebel College, University of Roehampton,

Roehampton Lane, SW15 5PJ, UK.

E-mail: emilyn.claid@roehampton.ac.uk 
Notes

${ }^{1}$ A translation of the South African philosophical concept of 'Ubunti', relating to human-ness.

2 Badiou is writing here of Jewish Law.

${ }^{3}$ Capital letters are applied in this writing to emphasize the so-called universal Meta narratives of these terms.

${ }^{4}$ In his essay on Ethics (2002) Badiou exposes how 'apostles of ethics' are in fact horrified by difference.

Respect for differences, of course! But on condition that the different be parliamentary-democratic, pro free-market economics, in favour of freedom of opinion, feminism, the environment... That is to say: I respect differences, but only, of course, in so far as that which differs also respects, just as I do, the said differences... The respect for differences applies only to those differences that are reasonably consistent with this identity (which, after all, is nothing other than the identity of a wealthy albeit visibly declining - "West")... The truth is that, in the context of a system of thought that is both a-religious and genuinely contemporary with the truths of our time, the whole ethical predication based upon recognition of the other should be purely and simply abandoned. For the real question - and it is an extraordinarily difficult one - is much more that of recognising the Same. (Badiou 2002:24-25 original emphasis) 
5 See Williams (1996) 'Working (in) the in-between', for an insightful account of contact improvisation as an ethical practice.

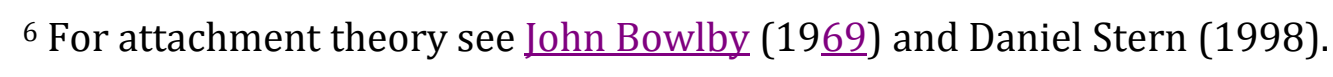

7 The conference keynote address included participatory tasks, which complimented the content of the text. These are included as performative actions. This task is familiar to contact improvisation practitioners and reflects

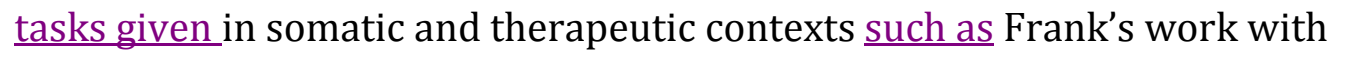
developmental movement patterns (Frank and LeBarre 2011).

8 This is Task Two at the conference and is taken from Falling - A Creative Process, a practice led research project based on metaphorical, physical and psychological acts of falling (see Claid_2014),

${ }^{9}$ In parallel and referencing earlier writing (Claid 2014), intersubjective contact between self and other is socially described as keeping face, a 'line' (Goffman [1967]2005: 5) of behaviour by which an individual is known in the world, by others and himself. To keep face is to maintain a consistent image of self in relation to others. You and I understand each other to exist through the faces that we show to each other and this line is maintained through our face-to-face responses. 'At such times the person's face clearly is something that is not lodged in or on his body, but rather something that is diffusely located in the flow of events in the encounter' (Goffman [1967] 2005:6-7).

10 The Simpsons is an American animated sitcom created by Matt Groenig for the Fox Broadcasting Company.

${ }^{11}$ I refer here to a Deleuzian sense of encounter: 
something in the world forces us to think. This something is an object not of recognition but of a fundamental encounter. It may be grasped in a range of affective tones: wonder, love, hatred, suffering. In whichever tone, its primary characteristic is that it can only be sensed. In this sense it is opposed to recognition. (Deleuze 2004: 139)

12 I performed this action during the keynote address at the Somatics and Ethics Conference (2015).

\section{3 https://en.wikipedia.org/wiki/Dash.}

${ }^{14}$ Important here is the use of the term 'in between', rather than 'the between', which as Gestalt psychologist and therapist Stawman points out is ' a "notional space" or "process" that surely remains, to the extent that it exists at all, beyond individual grasp... I can never step outside my experience' (Stawman 2009:20). 15 Philosopher, theologian, political activist and educator Martin Buber differentiates dialogic relational contact (I-Thou) from an encounter where someone stands outside as observer (I-It), yet 'I' is always in relationship and both stances are necessary for relational encounter.

The chief presupposition for the rise of genuine dialogue is that each should regard his partner as the very one he is. I become aware of him, aware that he is different, essentially different from myself, in the definite, unique way which is peculiar to him, and I accept whom I thus see, so that in full I can direct what I say to him as the person he is (Buber 1965:79) 
16 I have written elsewhere about this white dance privilege $(2006,2015)$, how the issues for black dancers in the 1970 s and 80 s were very different. While we were busy undoing and letting go of fixed codes and identities, many black artists were trying to establish an identity in the first place. How can you let go of your identity if identity has never been recognized as yours in the first place? (see also, Adair and Burt 2013),

17 See Miranda Tufnell and Chris Crickmay Body Space Image (2014) for ways in which body and object, body and environment interweave.

18 http://www.criticaldance.org/2015/04/10/leading-choreographers-raiseconcerns-over-uk-contemporary-dance-training/. The morning I gave the keynote at the Somatic Conference 12 July 2015, was an article in The Guardian about this issue of training.

http://www.theguardian.com/stage/2015/jul/12/contemporary-dance-debateshechter-khan-newson-laban-students-training.

${ }^{19}$ Whether or not dance spectacle can continue to exist in the light of collaborative ethical processes is a topical question within current practice led choreographic research, addressed by artist researchers and improvisers such as Michael Klien, Rachel Gomme, Efrosini Protopapa, Andrew Morrish, Kirstie Simson, Luke Pell, Susanna Recchia, Siobhan Davies and at events such as What_Now 2014 at Independent Dance. Particularly contradictory is the vital present time questioning that occurs in improvisatory performance forms, compared to fixed choreography, as sensational relational present time action and repeated phrases of movement often negate each other. 
